\title{
MOVIMENTOS DA TERRA
}

\section{Apresentação: Relato de Experiência}

Autor principal: Micheline Patriota Lima e Silva ${ }^{1}$;

Orientador: Alberto Alexandre Lima de Almeida ${ }^{2}$

\section{Introdução}

O presente relato procura apresentar experiências desenvolvidas durante a formação no curso de licenciatura em Geografia do IFRN( campus Natal/central) no período 2015 a 2016 . O mesmo retrata uma intervenção pedagógica desenvolvida em duas etapas: a primeira, consistia em desenvolver técnicas ou metodologias que viabilizassem a aprendizagem de alunos com deficiência visual, enquanto proposta de atividade da disciplina de Educação Inclusiva; a segunda, enquanto atividade integrante do PIBID (Programa Institucional de Bolsas de Iniciação à Docência), no qual as estratégias desenvolvidas na primeira etapa eram apresentadas às escolas parceiras do programa.

\section{Relato de Experiência}

O objetivo estava relacionado à necessidade de elaborar um material didático destinado a alunos com necessidades educacionais especiais, com foco nos conteúdos arrolados no componente curricular de Geografia. Desta forma, O tema escolhido foi "Movimentos da Terra”, o qual permitiu a construção de uma maquete articulada contendo a Terra, o Sol e Lua, na qual os alunos percebessem toda a dinâmica desses movimentos, e sua importância para o planeta, como também a origem do dia e da noite, os solstícios e equinócios, as estações do ano e a ocorrência dos eclipses. Desse modo, através de uma representação física, palpável, foi possível abordar um conteúdo abstrato e cuja abstração se torna ainda mais intensa quando se

\footnotetext{
${ }^{1}$ Licenciatura em Geografia, Instituto Federal de Educação, Ciência e Tecnologia do Rio Grande do Norte (IFRN), bolsista do Programa Institucional de Bolsas de Iniciação à Docência, no subprojeto de Geografia do IFRN, michelinepatriot@gmail.com.

${ }^{2}$ Profo. Mestre em Educação, Instituto Federal de Educação, Ciência e Tecnologia do Rio Grande do Norte (IFRN), alberto.almeida@ifrn.edu.br.
} 
trata de alunos com deficiência visual, o que foi o caso dos 4 alunos envolvidos nesse trabalho, realizado nas dependências da Escola Estadual Almirante Newton Braga, localizada no bairro do Alecrim, Natal/RN, com turmas do $6^{\circ}$ ano do ensino fundamental.

A demonstração foi feita individualmente, para que todos pudessem ter o contato com a maquete, e assim representar os movimentos que haviam sido relatados, oportunizando uma melhor compreensão e representação do assunto trabalhado.

Como avaliação de aprendizagem, foi solicitado aos alunos que se posicionassem como foi demonstrado na maquete, para que os mesmos exercessem o papel da Terra, do sol e da lua, simulando os movimentos de rotação e translação entre si. Dessa forma, foi possível observar a apreensão do conteúdo enfocado.

Diante do exposto, corroboramos com Antunes (2013, p.94), quando reitera que "o conhecimento se dá na relação sujeito-objeto-realidade, com a intermediação do professor e pela ação do educando sobre o objeto de estudo". Nesse sentido, é necessário ir além das limitações impostas por um conteúdo puramente abstrato e desprovido de significado para os alunos.

O segundo momento aborda a utilização do mesmo experimento em escolas parceiras do PIBID, em salas de aula regular, onde o material desenvolvido foi apresentado como representação cartográfica do nosso Sistema Solar estimulando a aprendizagem dos educandos. A eficácia desse modelo pôde ser comprovada através de eventos como a "Amostra de Astronomia" e a "Oficina de cartografia", promovidas pelo PIBID e realizadas na Escola Estadual Castro Alves, situada no bairro de Nova Descoberta, Natal/RN.

Também de acordo com Carlos (2011, p.70), “a percepção espacial e a linguagem gráfica e cartográfica, trabalhadas desde os primeiros anos da educação básica, são aspectos fundamentais para a evolução das estruturas cognitivas e para o crescimento intelectual de crianças e adolescentes". Nesse sentido, os estudos de natureza cartográfica assumem uma significativa importância, para o ensino de Geografia e demais componentes curriculares.

\section{Considerações finais}

Destacamos a importância do ensino cartográfico, como indispensável no conhecimento do ensino geográfico, para tanto, se faz necessário que o professor intermediador utilize recursos, que são imprescindíveis na percepção, compreensão e aprendizado dos alunos. Conhecendo a realidade da rede pública de ensino, cabe ao professor, desenvolver metodologias para um melhor ensino-aprendizagem que contemple todos os alunos, inclusive aqueles que apresentam necessidades educacionais especiais.

\section{Referências:}

ANTUNES, C. As inteligências múltiplas e seus estímulos. $17^{\circ}$ ed. Campinas, SP: Papirus,2012.p. 94.

CARLOS, A. F.A. et al. A Geografia na Sala de Aula. $9^{\circ}$ ed. São Paulo: Contexto, 2011. 